\title{
Publicly funded, pegylated interferon-alpha treatment in British Columbia: Disparities in treatment patterns for people with hepatitis $C$
}

\author{
Priscilla C Hsu MHA ${ }^{1,2}$, Jane A Buxton MBBS MHSc ${ }^{1,2}$, Andrew W Tu MSc ${ }^{1}$, \\ Warren D Hill PhD ${ }^{1}$, Amanda Yu BSc${ }^{1}$, Mel Krajden MD FRCPC ${ }^{1}$
}

PC Hsu, JA Buxton, AW Tu, WD Hill, A Yu, M Krajden. Publicly funded, pegylated interferon-alpha treatment in British Columbia: Disparities in treatment patterns for people with hepatitis C. Can J Gastroenterol 2008;22(4):359-364.

BACKGROUND: An estimated 60,000 British Columbians are chronically infected with the hepatitis $\mathrm{C}$ virus (HCV); $10 \%$ to $20 \%$ will develop cirrhosis after 20 years and $5 \%$ to $10 \%$ of these will develop hepatocellular carcinoma. Although treatment may prevent cirrhosis and liver cancer, and improve quality of life, availability is limited.

METHODS: Individuals with HCV genotypes 1, 4, 5 and 6 who underwent baseline HCV-RNA tests between January 1, 2003 and December 31, 2005, and were eligible for publicly funded treatment through PharmaCare were linked to British Columbia's reportable disease database. Patterns in treatment were examined, including age at treatment, sex, location, time to treatment from HCV diagnosis and seasonality of treatment.

RESULTS: When corrected for HCV prevalence, men were more likely to receive treatment than women (RR 1.16, 95\% CI 1.02 to 1.31). Patients aged 35 to 54 years and 55 years or older were 3.45 times (95\% CI 2.80 to 4.26 times) and 4.49 times (95\% CI 3.55 to 5.69 times), respectively, more likely to initiate treatment than 15- to 34-year-olds. Differences were noted between health authorities. Patients in rural health service delivery areas (HSDAs) were 1.25 times (95\% CI 1.10 to 1.42 times) more likely to receive treatment than those in urban HSDAs. Patients had an average lapse of four years between HCV diagnosis and receiving treatment. The highest proportion of patients initiated therapy between January and March (36.5\%), with the lowest between October and December (less than 14\%).

CONCLUSIONS: This data linkage enabled us to identify populations less likely to receive publicly funded treatment. Rural HSDAs have higher rates of therapy initiation; this pattern merits further research but may be a result of integrated prevention and care projects in rural areas. Policy changes to the current PharmaCare funding co-payment schedules could reduce seasonal variability of treatment initiations throughout the year.

Key Words: HCV; Hepatitis C virus; Pegylated interferon; Ribavirin; Therapy; Treatment

T is estimated that more than 170 million people worldwide, Including 250,000 Canadians, are chronically infected with the hepatitis $\mathrm{C}$ virus (HCV) (1-3). British Columbia (BC) was the first province in Canada to make $\mathrm{HCV}$ reportable in 1992 (2). Since then, more than 58,000 people with HCV
Le traitement à l'interféron alpha pégylé

financé par le gouvernement en ColombieBritannique : Les disparités dans le mode de traitement des personnes atteintes d'hépatite $\mathrm{C}$

\begin{abstract}
HISTORIQUE : On estime que 60000 Britanno-Colombiens souffrent d'une infection chronique par le virus de l'hépatite C (VHC). De $10 \%$ à $15 \%$ d'entre eux ne sont pas traités et développent une maladie hépatique terminale. Le traitement peut prévenir la cirrhose et le cancer hépatique et améliorer la qualité de vie, mais il est peu disponible.
\end{abstract}

MÉTHODOLOGIE : Les personnes atteintes des génotypes 1, 4, 5 et 6 du VHC qui ont subi des tests de base de l'ARN-VHC entre le $1^{\text {er }}$ janvier 2003 et le 31 décembre 2005 et qui avaient droit à un traitement financé par le gouvernement par l'entremise de PharmaCare ont été à reliés la base de données des maladies à déclaration obligatoire de la ColombieBritannique. Les auteurs ont examiné les modes de traitement, y compris l'âge au moment du traitement, le sexe, le lieu, le délai de traitement après la diagnostic de VHC et le caractère saisonnier du traitement.

RÉSULTATS : Une fois les données corrigées pour tenir compte de la prévalence de VHC, les hommes étaient plus susceptibles d'être traités que les femmes (RR 1,16, $95 \%$ IC 1,02 à 1,31). Les patients de 35 à 54 ans et de 55 ans et plus étaient respectivement 3,45 fois (95\% IC 2,80 à 4,26 fois) et 4,49 fois ( $95 \%$ IC 3,55 à 5,69 fois) plus susceptibles d'entreprendre un traitement que les 15 à 34 ans. Les auteurs ont constaté des différences entre les autorités sanitaires. Les patients des zones de services de santé (ZSS) rurales étaient 1,25 fois (95 \% IC 1,10 à 1,42 fois) plus susceptibles d'être traités que ceux des ZSS urbaines. En moyenne, quatre ans s'écoulaient entre le diagnostic de VHC et le traitement. La plus forte proportion de patients entreprenaient le traitement entre janvier et mars (36,5\%) et la plus petite, entre octobre et décembre (moins de $14 \%$ ). CONCLUSIONS : Les liens établis entre les données ont permis aux auteurs de repérer les populations les moins susceptibles de recevoir un traitement financé par le gouvernement. Les ZSS rurales présentent un taux plus élevé d'initiation du traitement. Ce phénomène mérite des recherches plus approfondies mais peut découler de la prévention intégrée et des programmes de soins dans les régions rurales. Des changements de politiques aux échéanciers actuels de financement par quote-part de PharmaCare pourraient réduire la variabilité saisonnière d'initiation des traitements au cours de l'année.

${ }^{1}$ British Columbia Centre for Disease Control; ${ }^{2}$ Department of Health Care and Epidemiology, University of British Columbia, Vancouver, British Columbia

Correspondence: Dr Jane A Buxton, University of British Columbia, 655 West 12th Avenue, Vancouver, British Columbia V5Z 4R4. Telephone 604-660-6061, fax 604-660-0197, e-mail jane.buxton@bccdc.ca

Received for publication November 15, 2007. Accepted January 15, 2008. 


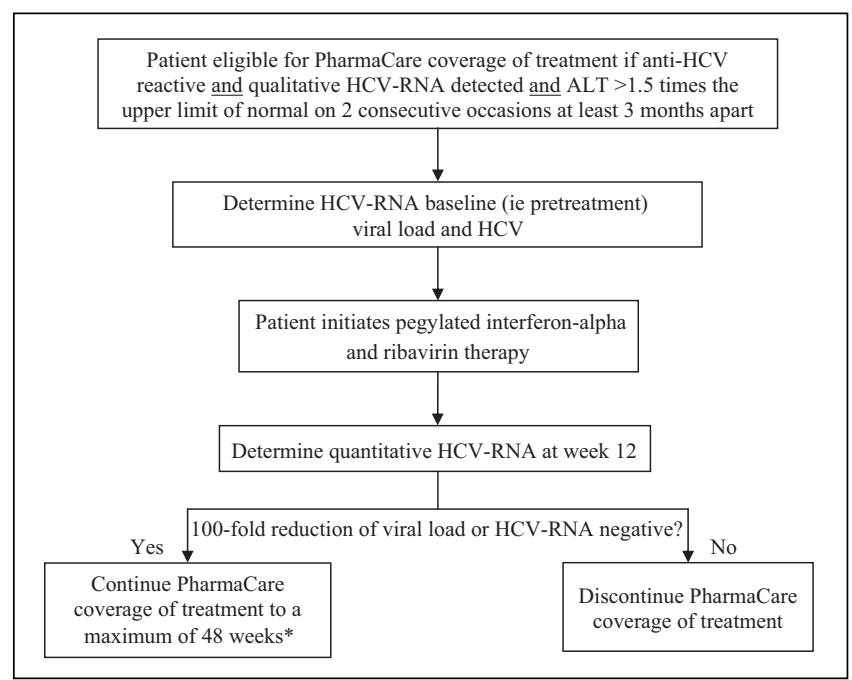

Figure 1) Summary of the British Columbia PharmaCare management protocol for the treatment of hepatitis $\mathrm{C}$ virus (HCV) genotypes $1,4,5$ and 6, using combination therapy of pegylated interferon-alpha and ribavirin. *PharmaCare coverage for treatment of HCV genotypes 2 and 3 is 24 weeks, with no renewals. ALT Alanine aminotransferase

communication, 2006). Chronic HCV infection may have serious consequences. Approximately $10 \%$ to $20 \%$ of those with chronic infection will develop cirrhosis after 20 years and of these, $5 \%$ to $10 \%$ will develop hepatocellular carcinoma $(1,4,5)$. HCV is now a major cause of chronic liver disease $(6,7)$ and is the leading indication for liver transplantation in developed countries (8-10). Current estimates of health care costs associated with $\mathrm{HCV}$ in Canada have placed the price tag at approximately $\$ 500$ million per year and is projected to reach more than $\$ 1$ billion by 2010 (11). Thus, it is critical that effective antiviral therapies are accessible to this population to prevent progression to endstage liver disease, where the cost burden to health care systems is the heaviest.

The current standard therapy for HCV is a combination of pegylated interferon-alpha $(\alpha)$ and ribavirin, which became available in BC in 2003. The recommended length of treatment and response depends on HCV genotype: 24 weeks of treatment for genotypes 2 and 3, with a sustained virological response (SVR) rate (ie, a negative HCV-RNA test result 24 weeks after therapy is completed) of $80 \%$; and 48 weeks of treatment for genotypes 1, 4, 5 and 6, with an SVR rate of $40 \%$ to $60 \%$ (12). In 2002, a study (13) conducted by the BC Centre for Disease Control (BCCDC) investigated acute $\mathrm{HCV}$ infections and estimated that $63 \%$ of infections were genotype $1,36 \%$ were genotypes 2 and 3 , and $1 \%$ were genotypes 4,5 and $6(n=2537)$. To date, systematic information on the treatment population in BC is limited. Therefore, we conducted a study of all patients in the province diagnosed with HCV genotypes 1, 4, 5 and 6 who were approved to receive publicly funded pegylated interferon- $\alpha$ and ribavirin combination therapy from PharmaCare from January 1, 2003 to December 31, 2005. Therapy data for genotypes 2 and 3 are not available. Although PharmaCare requires evidence of a 12-week viral load drop to continue treatment funding for genotypes 1, 4, 5 and 6, genotypes 2 and 3 automatically receive the full 24 weeks of treatment funding without further monitoring. The objectives of the present study were to describe the characteristics of this treated population and to determine differences in treatment rates by demographics, location, population density, time to treatment from initial report of HCV and seasonality of treatment initiation.

\section{METHODS}

\section{Data source}

Three data sources were used for the present study: the BCCDC Laboratory Information System (BCCDC-LIS), the Integrated Public Health Information System (iPHIS) and the BCCDC PharmaCare Decision Support Database (BCCDC-PDSD). The data stored in the BCCDC-LIS contain more than $95 \%$ of the HCV antibody tests and 75\% of the HCV-RNA tests conducted in BC, including data on all HCV genotypes since 2001. The BC regional health authorities report newly identified HCV cases within their geographical area into the iPHIS, the $\mathrm{BC}$ reportable disease database. The BCCDC epidemiology service collates, analyzes and interprets the data in the iPHIS to identify trends throughout the province.

The BCCDC-PDSD is a drug coverage approval and reporting system for PharmaCare, a BC government prescription drug program. BCCDC-PDSD contains demographic information and laboratory results of patients with HCV genotypes 1, 4, 5 and 6 who are approved to receive PharmaCare coverage of pegylated interferon- $\alpha$ and ribavirin combination therapy; it sends regular updates to PharmaCare so that they may determine whether to continue coverage of therapy for patients. The BCCDC-PDSD contains information on individuals eligible for Pharmacare coverage of HCV treatment only; information on people paying for therapies through other avenues (eg, out-of-pocket or private insurance) are not included. Since June 2003, pegylated interferon- $\alpha$ and ribavirin combination therapy has been available through PharmaCare. To qualify for PharmaCare coverage of $\mathrm{HCV}$ treatment in $\mathrm{BC}$, a patient must be anti-HCV reactive, have qualitative $\mathrm{HCV}$ RNA detected and have an alanine aminotransferase level higher than 1.5 times the upper limit of normal on two consecutive occasions at least three months apart. A liver biopsy is not required for $\mathrm{HCV}$ treatment initiation in $\mathrm{BC}$. The initial PharmaCare coverage for people infected with HCV genotypes $1,4,5$ or 6 , is 14 weeks of treatment, which may be continued for an additional 34 weeks if the patient responds to therapy, as measured by a viral load reduction of 100 -fold or undetectable HCV-RNA at 12 weeks. Figure 1 summarizes the PharmaCare treatment protocol.

\section{Procedure}

The BCCDC-PDSD was linked with 1992 to 2005 iPHIS data by a Personal Health Number. Data extracted from the iPHIS included date of birth, sex, HCV report date (ie, date the HCV case was first identified and reported in BC) and reporting health service delivery area (HSDA) (ie, residence of the $\mathrm{HCV}$ patient at the time of the report). BC has five geographic health authorities divided into 16 HSDAs (Figure 2, Table 1). The BCCDC-PDSD contained date of birth, sex, HCV genotype, and baseline and week $12 \mathrm{HCV}$-RNA results. The baseline HCV-RNA result represents the test result when approved for treatment, not the first ever HCV-RNA test. If duplicate baseline or 12-week HCV-RNA tests were found, the most recent was used for analysis. The BCCDC-LIS data were used 


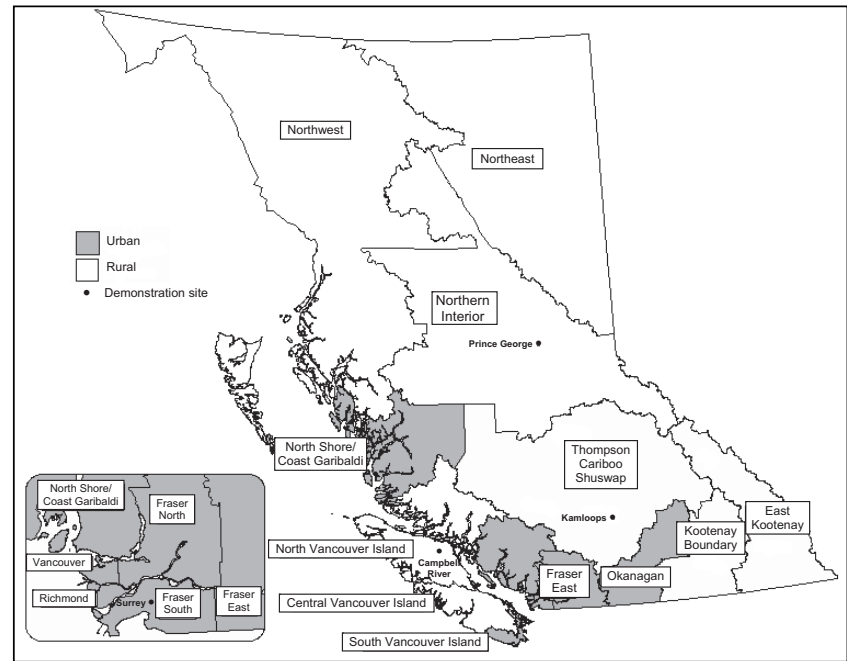

Figure 2) Classification of urban and rural health service delivery areas in British Columbia. Adapted from reference 31

to estimate the percentage of HCV genotypes 1, 4, 5 and 6 for each investigative characteristic, and these estimates were multiplied to the total number of people reported with $\mathrm{HCV}$ in the iPHIS $(n=54,356)$ for each respective characteristic. If duplicate HCV report dates were found in the iPHIS, the earliest reported date was used for analysis. The date of birth and sex stored in the BCCDC-PDSD were used for analysis if the respective data were missing in the iPHIS. The treatment start date was estimated by subtracting 84 days from the 12-week HCV-RNA test date. An HSDA with a city whose population was greater than or equal to 100,000 according to the 2005 BC Municipal Population Estimates (14) by BC Stats (the central statistical agency of $\mathrm{BC}$ ) was classified as an urban area and a city with a population of less than 100,000 was classified as a rural area (Figure 2). After the linkage and before analysis, the data were stripped of personal identifiers to protect the confidentiality of patients. The study was approved by the Clinical Research Ethics Board at the University of British Columbia (Vancouver, British Columbia).

\section{Sample selection}

HCV cases with genotypes 1, 4, 5 and 6 who had a baseline HCV-RNA test result in BCCDC-PDSD from January 1, 2003 to December 31, 2005 were included. Non-naive (ie, previously treated) patients, those missing 12-week HCV-RNA results and those whose baseline HCV-RNA test date in BCCDC-PDSD came before the date their HCV was reported in the iPHIS, were excluded.

\section{Analyses}

Data analyses were performed using SPSS 13.0 for Windows (SPSS Inc, USA). Descriptive statistics of demographic data for the sample population were reported and frequency distributions of patients initiating therapy were plotted by age and sex. Percentages treated were compared with total HCV reported cases in the iPHIS between 1992 and 2005; RRs and 95\% CIs were calculated. The time periods from reporting of HCV to treatment start date were calculated. The number of people initiating therapy were plotted quarterly from 2004 to 2005.
TABLE 1

Proportions of individuals with hepatitis $\mathrm{C}$ virus (HCV) genotypes 1, 4, 5 and 6 on the British Columbia PharmaCare pegylated interferon-alpha and ribavirin treatment program and estimates of people reported with HCV genotypes 1, 4, 5 and 6 in the Integrated Public Health Information System (iPHIS) from 1992 to 2005, as well as the corresponding RRs

\begin{tabular}{|c|c|c|c|c|c|}
\hline Characteristic & $\begin{array}{c}\text { Treated, } \\
\mathbf{n}\end{array}$ & $\begin{array}{l}\text { Estimated } \\
\text { reported }^{*}, n\end{array}$ & $\begin{array}{c}\text { Treated, } \\
\%\end{array}$ & $\mathbf{R R}$ & $95 \% \mathrm{Cl}$ \\
\hline \multicolumn{6}{|l|}{ Sex } \\
\hline Male & 788 & 23,045 & 3.42 & $1.16^{\ddagger}$ & $1.02-1.31$ \\
\hline Female & 342 & 11,606 & 2.95 & 1.00 & \\
\hline \multicolumn{6}{|l|}{ Age, years } \\
\hline $15-34$ & 96 & 8748 & 1.10 & 1.00 & \\
\hline $35-54$ & 811 & 20,851 & 3.89 & $3.45^{\ddagger}$ & $2.80-4.26$ \\
\hline $55+$ & 223 & 4349 & 5.13 & $4.49^{\ddagger}$ & $3.55-5.69$ \\
\hline \multicolumn{6}{|l|}{ Health Authority } \\
\hline Fraser & 344 & 10,267 & 3.35 & 1.00 & \\
\hline East $^{\dagger}$ & 72 & 2563 & 2.81 & & \\
\hline North ${ }^{\dagger}$ & 124 & 4171 & 2.97 & & \\
\hline South $^{\dagger}$ & 148 & 3566 & 4.15 & & \\
\hline Vancouver Island & 262 & 6545 & 4.00 & $1.19^{\ddagger}$ & $1.01-1.39$ \\
\hline South $^{\dagger}$ & 98 & 3189 & 3.07 & & \\
\hline North & 63 & 1272 & 4.95 & & \\
\hline Central & 101 & 2114 & 4.78 & & \\
\hline Vancouver Coastal & 285 & 10,180 & 2.80 & $0.84^{\ddagger}$ & $0.72-0.98$ \\
\hline Vancouver ${ }^{\dagger}$ & 187 & 7924 & 2.36 & & \\
\hline Richmond $^{\dagger}$ & 44 & 671 & 6.56 & & \\
\hline \multicolumn{6}{|l|}{ Coast Garibaldi ${ }^{\dagger}$} \\
\hline Interior & 169 & 4964 & 3.40 & 1.02 & $0.85-1.22$ \\
\hline Okanagan ${ }^{\dagger}$ & 87 & 2348 & 3.71 & & \\
\hline East Kootenay & 12 & 389 & 3.09 & & \\
\hline $\begin{array}{l}\text { Kootenay } \\
\text { Boundary }\end{array}$ & 20 & 589 & 3.39 & & \\
\hline \multicolumn{6}{|l|}{ Cariboo Shuswap } \\
\hline Northern & 70 & 1979 & 3.54 & 1.05 & $0.82-1.36$ \\
\hline Northwest & 11 & 493 & 2.23 & & \\
\hline Northeast & 7 & 337 & 2.08 & & \\
\hline Northern Interior & 52 & 1142 & 4.55 & & \\
\hline \multicolumn{6}{|l|}{ Population density } \\
\hline Urban & 814 & 25,977 & 3.13 & 1.00 & \\
\hline Rural & 316 & 7980 & 3.96 & $1.25^{\ddagger}$ & $1.10-1.42$ \\
\hline
\end{tabular}

${ }^{*}$ Estimates are derived from the percentage of genotypes 1, 4, 5 and 6 in the $B C$ Centre for Disease Control Laboratory Information System and multiplied by the total number of people reported with HCV in the iPHIS $(n=54,356)$ for each characteristic; ${ }^{\dagger}$ Classified as an urban health service delivery area; $\mp$ Values represent $P<0.05$

\section{RESULTS}

One thousand five hundred fifty-two patients in the BCCDCPDSD with HCV genotypes 1, 4, 5 and 6 were identified in the study period. Of these, 422 were excluded, leaving 1130 patient cases to be included in the study (Table 2 and Figure 3 ). The mean age was 48 years and more than two-thirds were male. When corrected for HCV prevalence, males were more likely to receive treatment than females (RR 1.16, 95\% CI 1.02 to 1.31) (Table 1). More males received treatment than 
TABLE 2

Demographic characteristics of the hepatitis $\mathrm{C}$ virus study population $(n=1130)$

\begin{tabular}{|c|c|}
\hline Characteristic & Patients \\
\hline Age at treatment, years, mean \pm SD & $48.3 \pm 8.8$ \\
\hline \multicolumn{2}{|l|}{ Sex, n (\%) } \\
\hline Male & $788(69.7)$ \\
\hline Female & $342(30.3)$ \\
\hline \multicolumn{2}{|l|}{ Health Authority, $\mathrm{n}(\%)$} \\
\hline Fraser & $344(30.4)$ \\
\hline Vancouver Coastal & $285(25.2)$ \\
\hline Vancouver Island & $262(23.2)$ \\
\hline Interior & $169(15.0)$ \\
\hline Northern & $70(6.19)$ \\
\hline \multicolumn{2}{|l|}{ 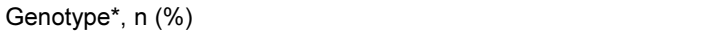 } \\
\hline 1 & $589(52.1)$ \\
\hline $1 \mathrm{a}$ & $175(15.5)$ \\
\hline $1 \mathrm{~b}$ & $374(33.1)$ \\
\hline 4 & $22(1.95)$ \\
\hline 5 & $1(0.09)$ \\
\hline 6 & $9(0.80)$ \\
\hline \multicolumn{2}{|l|}{ Year reported, n (\%) } \\
\hline Before 1996 & $108(9.56)$ \\
\hline 1996 to 2000 & $433(38.3)$ \\
\hline 2001 to 2005 & $589(52.1)$ \\
\hline \multicolumn{2}{|l|}{ Year treated, n (\%) } \\
\hline 2003 & $255(22.6)$ \\
\hline 2004 & $467(41.3)$ \\
\hline 2005 & $408(36.1)$ \\
\hline Years from reported to treated, mean \pm SD & $4.08 \pm 3.20$ \\
\hline Years from reported to treated, median, range & $3.37(<1-13)$ \\
\hline \multicolumn{2}{|l|}{ Population density, n (\%) } \\
\hline Urban & $814(72.0)$ \\
\hline Rural & $316(28.0)$ \\
\hline
\end{tabular}

${ }^{*}$ Percentages add up to more than $100 \%$ because of co-infection of multiple genotypes

females in every age category except for younger (15 to 29 years) and older (60 to 64 years) age groups (Figure 4). Compared with patients in the youngest age category of 15 to 34 years, patients aged 35 to 54 years and patients aged 55 years or older were significantly more likely to initiate treatment (RR 3.45 and 4.49, respectively). The mean $( \pm \mathrm{SD})$ time interval between reporting of $\mathrm{HCV}$ and receiving treatment was $4.08 \pm 3.20$ years; $38 \%$ of patients were treated within two years of being reported with $\mathrm{HCV}$ and less than $5 \%$ waited 10 years or more to receive treatment.

Treatment rates varied among and within each health authority (Table 1). The Fraser Health Authority treated the largest number patients of all the health authorities, but ranked second last when comparing treated cases to reported HCV cases. Patients in the Vancouver Island Health Authority were most likely to receive treatment, while patients in the Vancouver Coastal Health Authority were the least. Although the Vancouver HSDA had the highest number of HCV cases treated of any HSDA, it had the lowest treatment rate when corrected for $\mathrm{HCV}$ prevalence (excluding two HSDAs with small numbers and hence unstable rates).

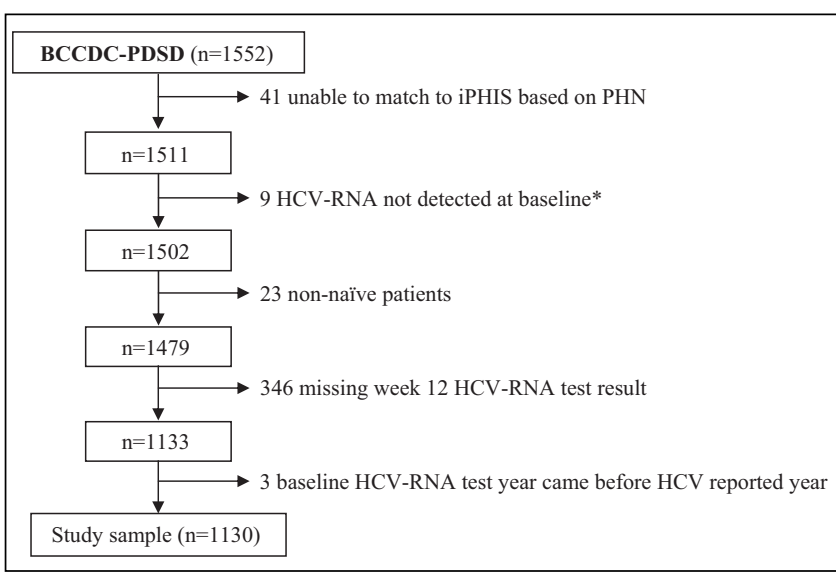

Figure 3) Summary of the July 2006 linkage of the BC Centre for Disease Control PharmaCare Decision Support Database (BCCDCPDSD) and the Integrated Public Health Information System (iPHIS) for people with hepatitis $\mathrm{C}$ virus (HCV) genotypes 1, 4, 5 and 6 on the PharmaCare pegylated interferon-alpha and ribavirin treatment program. *The BCCDC-PDSD should contain individuals with HCVRNA detected at baseline, so the nine patients with undetected HCV-RNA at baseline were excluded due to errors in the database. PHN Personal Health Number

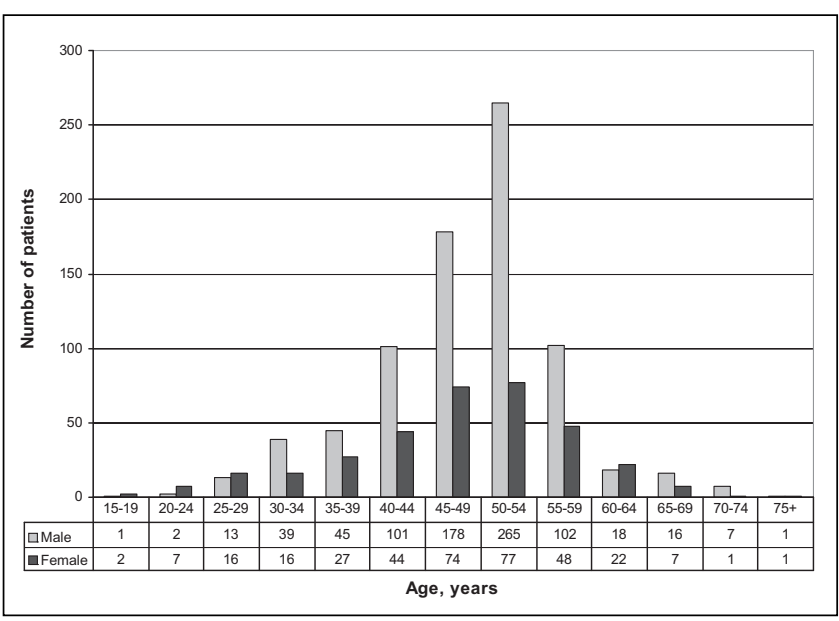

Figure 4) Number of patients $(n=1130)$ with hepatitis $C$ virus genotypes 1, 4, 5 and 6 on the PharmaCare pegylated interferon-alpha and ribavirin treatment program from January 1, 2003 to December 31, 2005 , stratified by age and sex

Patients in rural areas were 1.25 times more likely to receive treatment than patients in urban areas (95\% CI 1.10 to 1.42 ). Figure 5 shows the initiation of therapy by quarter and by geographic categories since therapy data became available in 2003.

\section{DISCUSSION}

We found that males and older individuals were more likely to be treated. Sex differences in alcohol consumption may result in males being more likely to progress to liver disease and require treatment. Older people may exhibit symptoms of liver damage because they have had the disease longer, and thus are more likely to seek health care and receive treatment. In younger age categories (younger than 30 years), we found that more females initiated treatment than males. Studies have 
shown that HCV infection rates are higher among young females than males of similar ages $(13,15,16)$ due to risk factors such as needle and equipment sharing, and assistance with injection (17-19). Young females may also experience increased HCV testing because of health care encounters for sexually transmitted disease testing, contraception and/or pregnancy. According to the BCCDC-LIS, more females (57\% to $65 \%$ ) are tested for HCV than males in younger age categories (15 to 29 years). Once infected, females have been shown to be more likely to clear HCV than males, resulting in more males actually needing treatment than females (13).

We found that patients in urban areas were less likely to initiate treatment than in rural areas. The number of $\mathrm{HCV}$ cases in urban areas might exceed the treatment capacity available. The BC Medical Association guidelines for the management of HCV lists ongoing drug abuse as a relative contraindication to antiviral therapy. However, many studies have shown that modified treatment strategies for substance dependence have been effective in attaining an SVR (20-25). An overall SVR rate of $65 \%$ was achieved by a study examining the treatment of $\mathrm{HCV}$ in injection drug users within a directly observed therapy program in BC (25). Because intravenous drug use is currently the most common risk factor for contracting HCV (26), it is possible that large numbers of socially marginalized individuals in urban areas, including Vancouver's downtown eastside, infected with HCV may be less likely to seek or be offered treatment. A study (27) conducted at a large liver disease clinic in Quebec found that risk factors usually associated with socially marginalized populations such as current intravenous drug use, alcoholic liver damage on biopsy, unstable housing arrangements and mental disorders were negatively associated with treatment initiation. It is interesting to note that although the Richmond HSDA is an urban area, it had the highest treatment rate of any HSDA. This may be because it has a small HCV population, which enables comprehensive follow-up, treatment and support by public health and health care providers.

Northern Interior, North Vancouver Island and Fraser South HSDAs had the highest treatment rates in their respective health authorities. This may be because each contains a hepatitis demonstration site (see Figure 2 for locations) developed in 2001 by BC Hepatitis Services and funded by the BC Ministry of Health to build local capacity and integrate prevention and care of hepatitis. A review of the demonstration sites from 2001 to 2004 found that they successfully integrated prevention, community development, education and support, as well as clinical services (28). Specialized nurses and collaborative teams help patients make treatment decisions and connect patients with health and social service support in a timely manner.

Many patients initiated treatment within two years of $\mathrm{HCV}$ diagnosis; these patients may have been tested for HCV because they were exhibiting symptoms of liver damage and therefore commenced treatment soon after HCV diagnosis. PharmaCare implemented the pegylated interferon- $\alpha$ and ribavirin treatment program in June 2003. Some people eligible for HCV treatment before June 2003 are reported to have deferred treatment until the new regimen was available (personal communication, Warren Hill). The trend of reduced treatment uptake in the latter quarters of 2004 and 2005 might be the result of PharmaCare's deductible-based drug coverage program payment schedule (29). Aside from people on income assistance who receive complete drug coverage, the majority of patients pay their full drug costs until they reach a maximum,

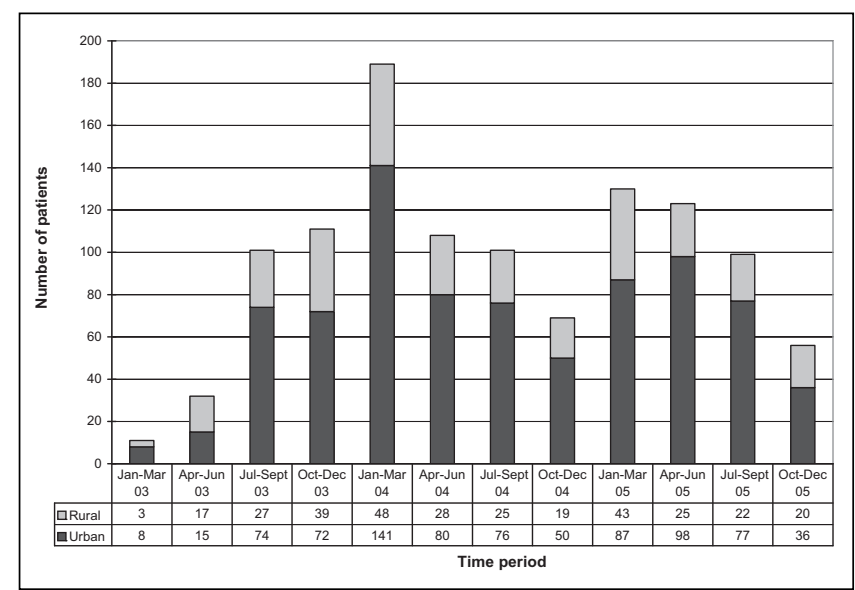

Figure 5) Number of patients $(n=1130)$ with hepatitis $C$ virus genotypes 1, 4, 5 and 6 on the PharmaCare pegylated interferon-alpha and ribavirin treatment program, from January 1, 2003 to December 31, 2005 , stratified by month of therapy initiation

income-based deductible; PharmaCare then pays for the remaining drug costs for that calendar year. For example, a patient with a family income of $\$ 50,000$ would pay $\$ 1,500$ before PharmaCare covers the remaining treatment costs. Because the treatment coverage for genotypes 1, 4, 5 and 6 is 48 weeks, a patient considering treatment at the end of the calendar year may opt to postpone their treatment until the beginning of the subsequent year to avoid paying the deductible twice. Therefore, patients may endure worsening symptoms and psychological distress while waiting for a more financially favourable time to begin treatment. From the system perspective, the peak in treatment initiation in the early months of each year can put unnecessary stress on the health care system. Other provinces with similar income-based universal drug coverage programs (eg, Quebec and Manitoba) might also be experiencing the same situation, where patients forgo or delay necessary treatments due to financial disincentives created by a system utilizing deductibles. Thus, it is worthwhile for federal and provincial governments to explore alternative drug funding mechanisms that promote equity, access and efficiency. These mechanisms might involve a blend of complete drug coverage for vulnerable populations and universal deductible-based drug coverage for entire populations (30).

There are several limitations to our study. The BCCDCPDSD only contains data for genotypes 1, 4, 5 and 6; therefore, we cannot make any conclusions for genotypes 2 and 3 . Our sample may have been biased by excluding patients without Personal Health Numbers who might be more likely to be homeless, have lower socioeconomic status and poorer access to treatment. Also, people on treatment in correctional facilities would have been identified as an HCV case in the iPHIS but, if treated, would be excluded from the BCCDC-PDSD because they are under federal jurisdiction. The exclusion of privately funded patients may influence the treatment patterns found in our study; for example, employed individuals with private drug plans may be more likely to be male, older or reside in urban areas. Because a liver biopsy is not required for HCV treatment initiation in $\mathrm{BC}$, our findings might not be generalizable to other jurisdictions that have different eligibility criteria for HCV therapy. Our estimation of the proportion of HCV genotypes $1,4,5$ and 6 from the BCCDC-LIS might have been 
inaccurate and that would have affected our estimation of HCV genotypes reported in the iPHIS and the accuracy of our RR values. However, our study population data was from 2003 to 2005, which falls within the time period (1992 to 2005) used to derive the genotype estimates from the BCCDC-LIS data. Another limitation is our definition of urban and rural; other definitions might have resulted in different results. For example, although the North Shore/Coast Garibaldi HSDA is classified as an urban area, a large portion includes rural coastal mainland further north. The HSDA for cases in the iPHIS is based on the location where it was first reported. Some people may have moved before treatment, especially those with a long lapse between $\mathrm{HCV}$ report and treatment initiation dates. Others may have been identified in a rural community but travel to an urban centre for treatment because of a lack of services in their community.

It is important to note that $20 \%$ of patients in our linked dataset did not have an HCV-RNA test at week 12; further research is needed to determine if these patients did not initiate treatment or if they dropped out of treatment before their week 12 tests and if so, these people might need more resources and social services support to assist them through the challenges of receiving HCV treatment.

\section{CONCLUSIONS}

Our study presented data from a publicly funded treatment program in BC, from 2003 to 2005. Patients who were older, male and who reported their $\mathrm{HCV}$ in rural areas were more likely to initiate treatment. Our findings suggest that the demonstration sites in rural areas of $\mathrm{BC}$ have higher $\mathrm{HCV}$ treatment rates in their surrounding areas. It is worthwhile to consider applying our knowledge of the demonstration sites and expanding these integrated services to other areas of $\mathrm{BC}$. Wider policy implications include revising the current PharmaCare funding guidelines for HCV treatment to achieve a balance of treatment initiations throughout the year.

ACKNOWLEDGEMENTS: The authors thank Maria Alvarez, Jennifer Cutler, Doug Ford and Wrency Tang for their assistance with the data linkage.

\section{REFERENCES}

1. Lauer GM, Walker BD. Hepatitis C virus infection. N Engl J Med 2001;345:41-52.

2. Zou S, Tepper M, Giulivi A. Current status of Hepatitis C in Canada. Can J Public Health. 2000;91(Suppl 1):S10-5, S10-6.

3. Remis R. A study to characterize the epidemiology of hepatitis $C$ in Canada, 2002. Final Report. 2004. Ottawa: Health Canada.

4. Seeff LB. Natural history of chronic hepatitis C. Hepatology 2002;36(5 Suppl 1):S35-46.

5. Alter MJ, Margolis HS, Krawczynski K, et al. The natural history of community-acquired hepatitis $\mathrm{C}$ in the United States. The Sentinel Counties Chronic non-A, non-B Hepatitis Study Team. N Engl J Med 1992;327:1899-905.

6. Deuffic S, Poynard T, Valleron AJ. Correlation between hepatitis C virus prevalence and hepatocellular carcinoma mortality in Europe. J Viral Hepat 1999;6:411-3.

7. El-Serag HB. Hepatocellular carcinoma: Recent trends in the United States. Gastroenterology 2004;127(5 Suppl 1):S27-34

8. Adam R, McMaster P, O'Grady JG, et al. Evolution of liver transplantation in Europe: Report of the European Liver Transplant Registry. Liver Transpl 2003;9:1231-43.

9. Saab S, Wang V. Recurrent hepatitis C following liver transplant: Diagnosis, natural history, and therapeutic options. J Clin Gastroenterol 2003;37:155-63.

10. Seaberg EC, Belle SH, Beringer KC, Shivins JL, Detre KM. Liver transplantation in the United States from 1987-1998: Updated results from the Pitt-UNOS Liver Transplant Registry. Clin Transpl 1998:17-37.

11. Fischer B, Haydon E, Rehm J, Krajden M, Reimer J. Injection drug use and the hepatitis $\mathrm{C}$ virus: Considerations for a targeted treatment approach - the case study of Canada. J Urban Health 2004;81:428-47.

12. Kim AI, Saab S. Treatment of hepatitis C. Am J Med 2005;118:808-15.

13. Shadmani R, Pourbohloul B, Butt G, et al. Population-based analysis of acute hepatitis $\mathrm{C}$ virus (HCV) infections and spontaneous virologic resolution based on gender and age in $\mathrm{BC}$, Canada. [Poster presentation]. The 40th Annual Meeting of the European Association for the Study of the Liver. Paris, April 13 to 17, 2005.

14. BCStats. BC Municipal Population Estimates, 1996-2006, Sorted by Name. <http://www.bcstats.gov.bc.ca/data/pop/pop/mun/ Mun9606a.asp. (Version current at March 7, 2008).

15. Zou S, Zhang J, Tepper M, et al. Enhanced surveillance of acute hepatitis B and C in four health regions in Canada, 1998 to 1999. Can J Infect Dis 2001;12:357-63.

16. Shatin D, Schech SD, Patel K, McHutchison JG. Population-based hepatitis $\mathrm{C}$ surveillance and treatment in a national managed care organization. Am J Manag Care 2004;10:250-6.

17. Evans JL, Hahn JA, Page-Shafer K, et al. Gender differences in sexual and injection risk behavior among active young injection drug users in San Francisco (the UFO Study). J Urban Health 2003;80:137-46.

18. Doherty MC, Garfein RS, Monterroso E, Latkin C, Vlahov D. Gender differences in the initiation of injection drug use among young adults. J Urban Health 2000;77:396-414.

19. Bennet GA, Velleman RD, Barter G, Bradbury C. Gender differences in sharing injecting equipment by drug users in England AIDS Care 2000;12:77-87.

20. Backmund M, Meyer K, Von Zielonka M, Eichenlaub D. Treatment of hepatitis $\mathrm{C}$ infection in injection drug users. Hepatology 2001;34:188-93.

21. Taylor LE, Schwartzapfel B, Allen S, Jacobs G, Mitty J. Extending treatment for $\mathrm{HCV}$ infection to HIV-HCV coinfected individuals with psychiatric illness and drug dependence. Clin Infect Dis 2003;36:1501-2.

22. Van Thiel DH, Anantharaju A, Creech S. Response to treatment of hepatitis $\mathrm{C}$ in individuals with a recent history of intravenous drug abuse. Am J Gastroenterol 2003;98:2281-8.

23. Sylvestre DL. Approaching treatment for hepatitis $\mathrm{C}$ virus infection in substance users. Clin Infect Dis 2005;41(Suppl 1):S79-82.

24. Matthews G, Kronborg IJ, Dore GJ. Treatment for hepatitis C virus infection among current injection drug users in Australia. Clin Infect Dis 2005:15;40(Suppl 5):S325-9.

25. Grebely J, Meagher C, Duncan F, et al. Treatment of hepatitis C virus (HCV) infection in injection drug users (IDUs) enrolled in a directly observed therapy (DOT) program. The 17th International Conference on the Reduction of Drug Related Harm., Vancouver, April 30 to May 4, 2006. (Abst)

26. Moirand R, Bilodeau M, Brissette S, Bruneau J. Determinants of antiviral treatment initiation in a hepatitis $\mathrm{C}$-infected population benefiting from universal health care coverage. Can J Gastroenterol 2007;21:355-61.

27. Butt G, Barichello F, Trustham A, Hill WD. A review of the staged implementation of hepatitis projects in regional health authorities: January 2001-January 2004. Vancouver: BC Centre for Disease Control.

28. Wolfe GS. Hepatitis C: The latest epidemic. Lippincotts Case Manag 2005;10:56-9.

29. Government of British Columbia: Ministry of Health. What is Fair PharmaCare. < http://www.health.gov.bc.ca/pharme/plani/ planiinfo.html $>$ (Version current at March 7, 2008).

30. Morgan SG, Willison DJ. Post-Romanow pharmacare: Last-dollar first...first-dollar lost? Healthc Pap 2004;4:10-20.

31. BC Stats. British Columbia health authorities and health service delivery areas. <http://www.bcstats.gov.bc.ca/DATA/pop/maps/ HA_HSDA_bw.pd> (Version current at March 19, 2008). 


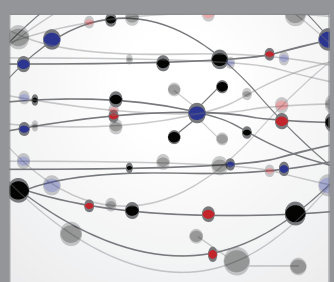

The Scientific World Journal
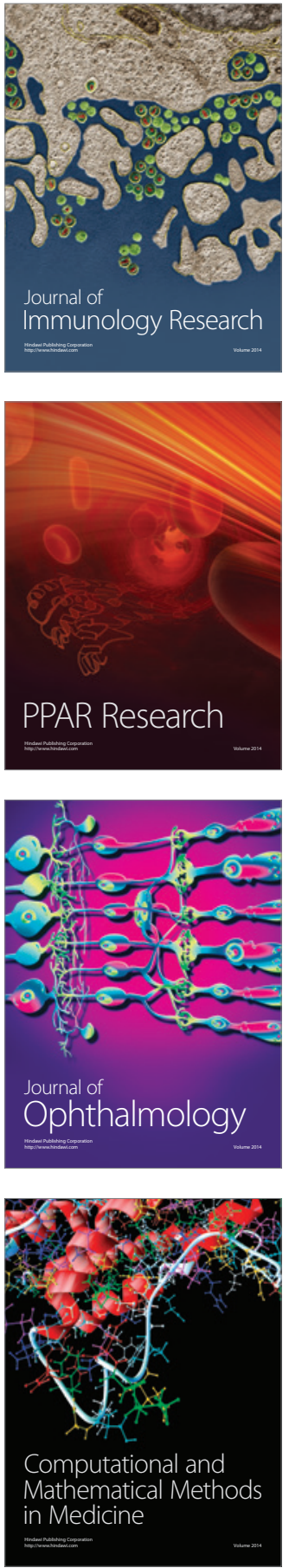

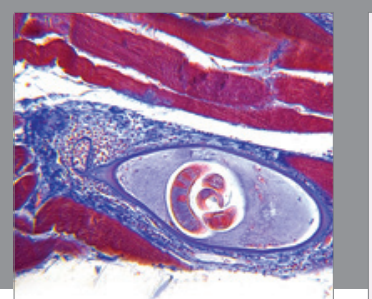

Gastroenterology Research and Practice

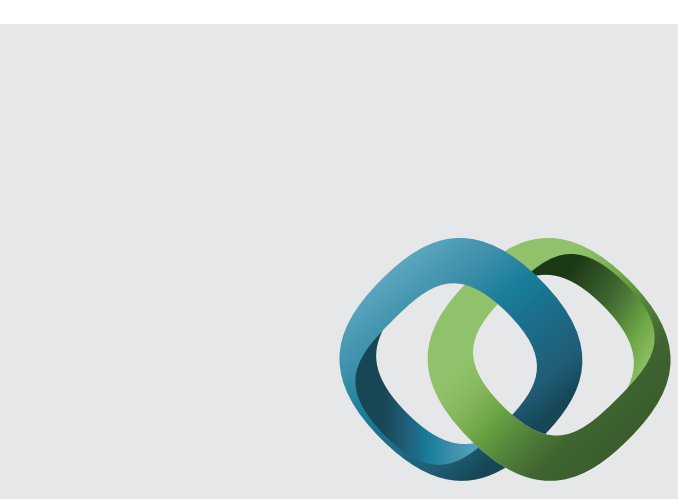

\section{Hindawi}

Submit your manuscripts at

http://www.hindawi.com
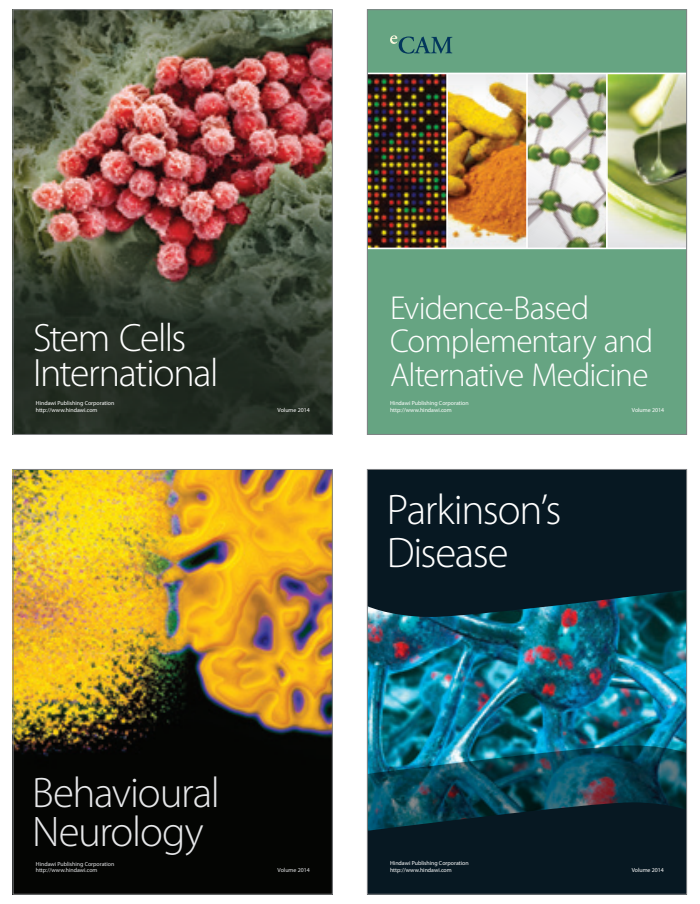
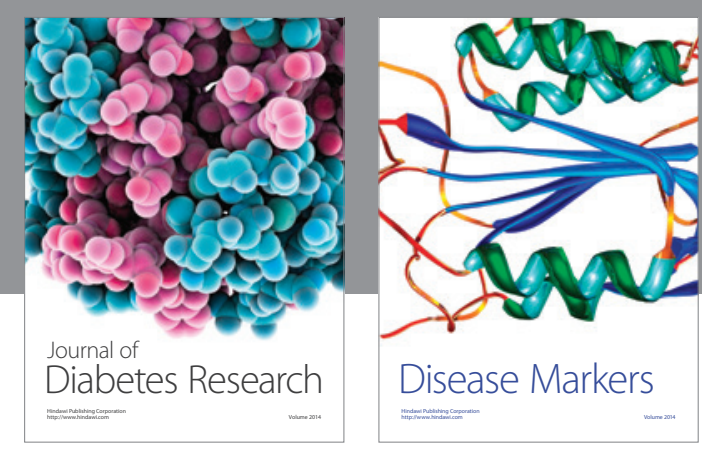

Disease Markers
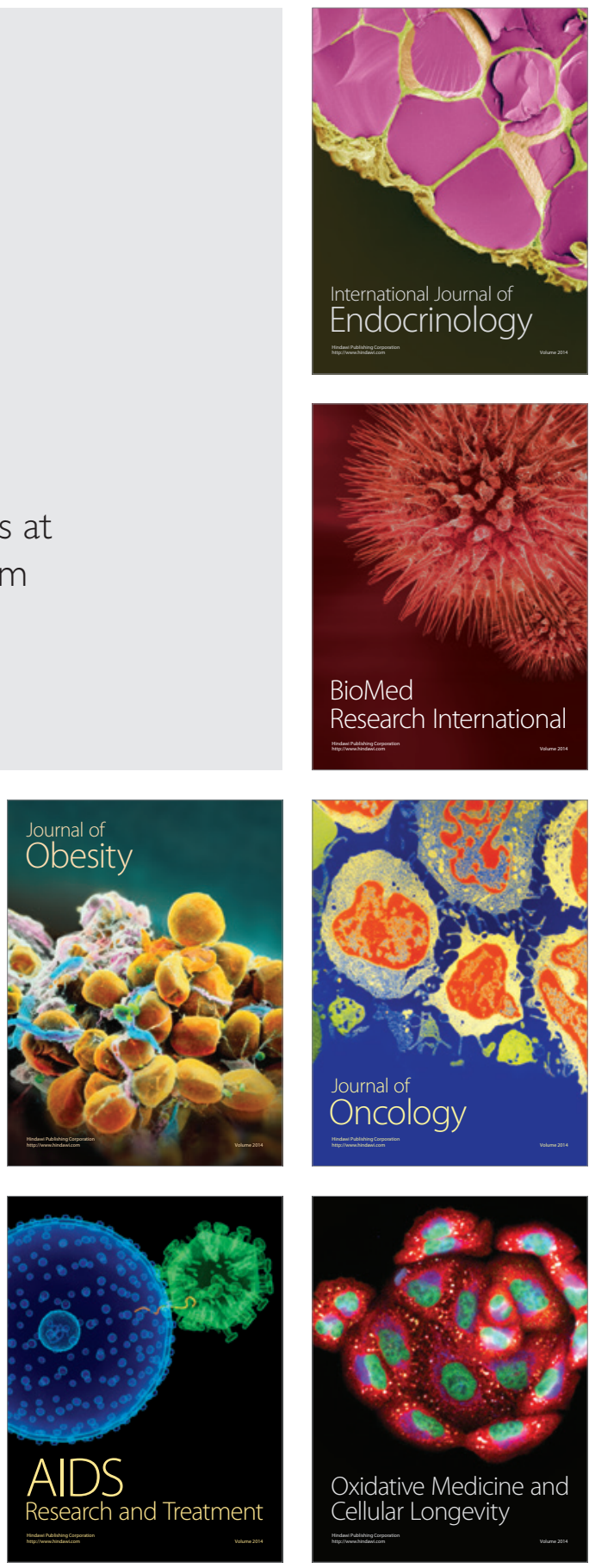